\title{
A study of highly phosphatic soils in a karst region of the humid tropics
}

\author{
H. SCHROO
}

Chief soil scientist with the former Government of Netherlands New Guinea

\section{Contents}

Su m m a r y

1. Introduction

1.1. First discoveries

1.2. Review of similar discoveries

1.3. A search for phosphorites

2. Geological survey

2.1. General data

2.2. Field work

2.3. The limestone samples

2.4. The soil samples

2.5. Retrospective considerations

3. Basic analyticaldata of a standard soil sample

3.1. The standard soil sample $B .6252$

3.2. Textural data

3.3. Available phosphate

3.4. Removal of phosphate by leacining

3.5. Total phosphate determination

3.6. The phosphate bearing compound $(X)$

3.7. Total analysis of sample B. 6252

3.8. Summary of results

4. Supplementory investigations in fieldand laboratory

4.1. Soil formation in dolines

4.2. Soil from the hillsides

4.3. Soil formation in uvalas

4.4. Relationship between the phosphate in soil and limestone

4.5. General principles of phosphate accumulation

4.6. The quantitative relation between soil and dissolving limestone

5. Occurrence and use of phosphatic limestone soils

5.1. Occurrence in West New Guinea

5.2. Industrial and commercial use

5.3. Agricultural use

Post scriptum

References

\section{Summary}

Soils developed on biohermal limestone in the karst region of the Ajamaroe platealu, contain High phosphate percentages which may amount to $30 \% \mathrm{P}_{2} \mathrm{O}_{5}$. The results obtained from a geological survey proved that the limestone involved was not a phosphorite but contained fairly normal

Received for publication 4th September, 1962. 
phosphate percentages from 0,02 to 0,70 with a general average of about $0,20 \% \quad \mathrm{P}_{2} \mathrm{O}_{5}$. Further analyses, carried out on a standard soil sample with $18,6 \% \mathrm{P}_{2} \mathrm{O}_{5}$, revealed that this silty clay sample had a remarkably low silicon content but contained high amounts of sesquioxides. Its calcium content was too small to allow for the presence of either di- or tri-calciumphosphate, whereas the presence of apatite or collophane in the soil was also ruled out. Further analytical evidence made it likely that the phosphate is present in the form of Crandallite 1. This secondary mineral is found to exist in coral limestone soils by other investigators; its formula is supposed to be $\mathrm{CaAl}_{3}\left(\mathrm{PO}_{4}\right)_{2}(\mathrm{OH})_{6}$. Together with iron oxides it is supposed to make up the bulk of the soil.

Pedological investigations carried out in the field and followed up by analytical studies of soil and limestone samples, confirmed the hypothesis that the highly phosphatic soils represents the accumulation product of insoluble and secondarily precipitated compounds originally contained in the limestone strata. Six principal rules are suggested which seem to control the outcome of this accumulative process and the final phosphate content of the soil in any one place. On account of these principles and the relation between specific weights of rock and soil, it is conceivable that not more than $75 \mathrm{~m}$ of limestone must dissolve to form $1 \mathrm{~m}$ of residual soil. Finally, the occurrence of this soil type in other parts of West New Guinea and the significance of this phosphatic material for industrial, commercial and agricultural use are briefly discussed.

1 See Post scriptum.

\section{Introduction}

\subsection{First discoveries}

Some years ago, early in 1958, the author was alerted by the finding of unusual high Truog values for available phosphate which were analyzed in a small batch of soil samples that was collected by the Government's agronomist near Ajamaroe. This village is situated in a large limestone region in the so-called "Bird's head" Peninsula of West New Guinea (see map FIGS. 1 and 2).

A subsequent assessment of the total phosphate contents of these soil samples, as determined by extraction with Fleischmann acid, i.e. $50 \%$ conc. $\mathrm{H}_{2} \mathrm{SO}_{4}+50 \%$ conc. $\mathrm{HNO}_{3}$, revealed even more puzzling figures which varied from 1 to $12 \% \mathrm{P}_{2} \mathrm{O}_{5}$. Thus far, the highest values obtained with this extraction method in our laboratory for other soils in New Guinea never exceeded the value of $0,5 \%$ total $\mathrm{P}_{2} \mathrm{O}_{5}$ which is considered to be "extremely high" for normal mineral soils.

Around the same time a general reconnaissance soil survey was carried out for 200.000 hectares in the same region by ReYNDERS and Razoux Schultz (1958), which survey yielded a much larger number of similar soil samples. Analysis of 65 of these samples proved that the occurrence of highly phosphatic soil near Ajamaroe was not incidentally, but that these soils could be found at random all over an area of 100.000 ha of limestone country. The Truog values of the samples ranged anywhere from 50 p.p.m. to 1000 p.p.m. $\mathrm{P}_{2} \mathrm{O}_{5}$. Likewise, the figures obtained for total phosphate contents varied considerably from site to site, being not less than $1 \%$ at the lowest and seldom more than $25 \% \quad \mathrm{P}_{2} \mathrm{O}_{5}$ at the highest. There was no distinct correlation between Truog values and total phosphate figures. In general, it appeared that for samples of each single profile the magnitude of the total phosphate figures was more or less constant, although, total phosphate tended to increase slightly with soil depth. The average figure for 10 samples from the top layer $2-20 \mathrm{~cm}$ was $5,1 \% \mathrm{P}_{2} \mathrm{O}_{5}$, whereas the average for the 10 corresponding samples from $20-50 \mathrm{~cm}$ depth was $6,5 \% \quad \mathrm{P}_{2} \mathrm{O}_{5}$. 
FIG. 1. Map of the Ajamaroe karst region
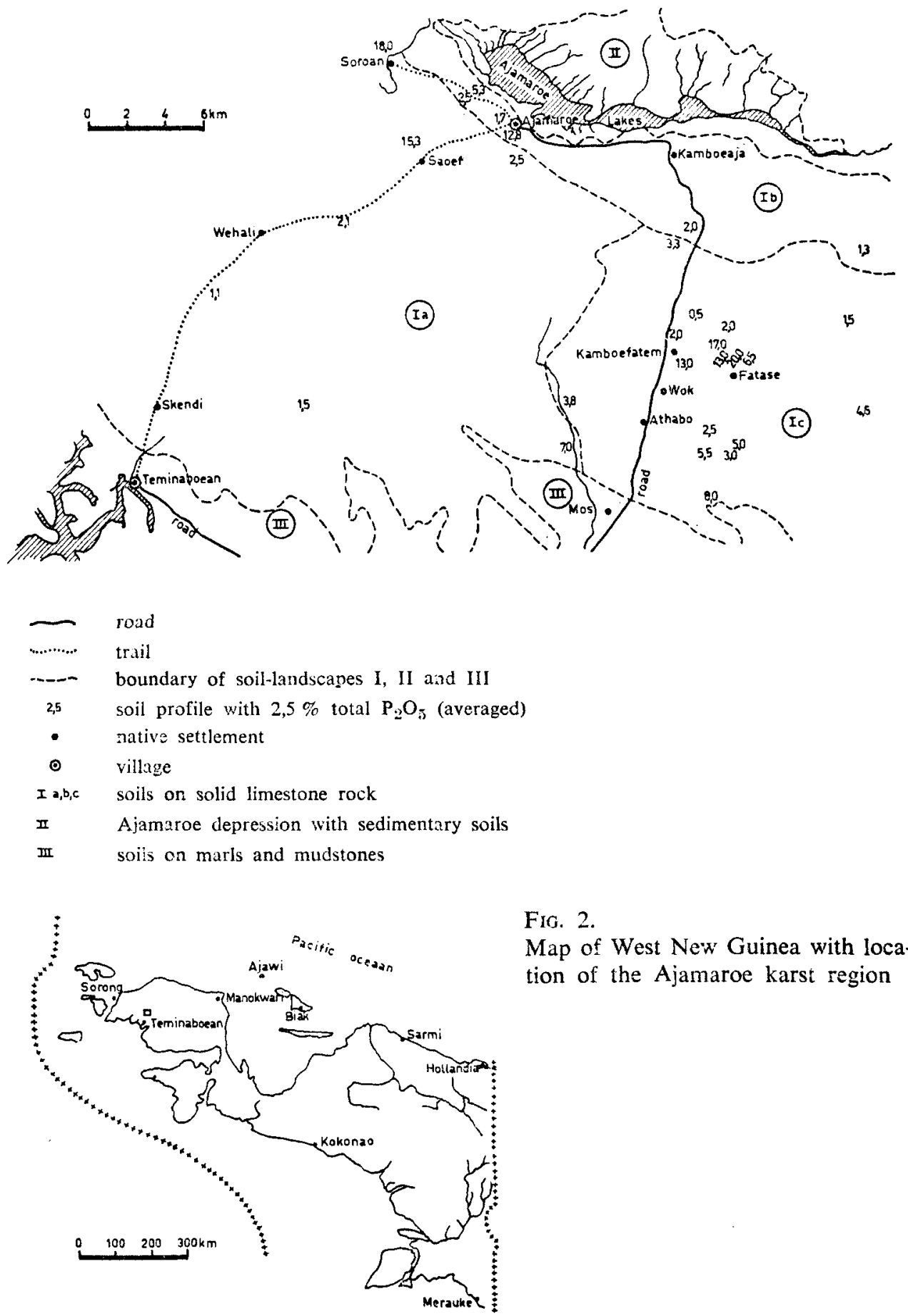

Fig. 2.

Map of West New Guinea with location of the Ajamaroe karst region 
In FIG. 1, these figures for total phosphate, averaged per profile, are indicated for 25 different sites within the actual karst landscape (Ia, b, c).

\subsection{Review of similar discoveries}

From available literature it appears that soils with similar high phosphate contents are reported to have been discovered in atoll islands of the Northern Marshall Group by Fosberg (1954). He describes certain coral sands under Pisonia forest that contain up to $5,6 \% \mathrm{P}_{2} \mathrm{O}_{5}$ in their humic $\mathrm{A}_{0}$-layer. Without further evidence, FosBerg presumes a constant staining of the soil surface with "guano", produced by sea-birds that are nesting in the trees. Due to the dissolving action of the acid, peaty Pisonia humus, the finely dispersed calcium phosphate contained in the "guano" is brought into solution and leached down into the B-horizon where it forms a phosphatic hardpan on contact with free calcium carbonate that analyzes up to $14 \% \mathrm{P}_{2} \mathrm{O}_{5}$. In other parts of the coral island, where these phosphatic hardpan are also found in the open field, the previous existence of Pisonia forest and 'guano' producing birds is assumed. A somewhat similar account is given by TERCINIER (1956), who describes soils with phosphatic top layers found in the Rangiroa atoll in the Touamoto Archipelago. These very stony or gravelly soils of the center of the emerged island are greatly enriched in humus and phosphorus in the upper part of their profile; they present a hardpan in their depth.

The subsequent soil layers at $0-8 \mathrm{~cm}, 10-25 \mathrm{~cm}, 30-45 \mathrm{~cm}$ and $60-85 \mathrm{~cm}$ of one of these profiles, analyze a total phosphate content of 2,$09 ; 1,14 ; 0,43$ and $0,21 \% \quad \mathrm{P}_{2} \mathrm{O}_{3}$, whereas their Truog values are 2000, 1260, 170 and 70 p.p.m. respectively. TERCINIER assumes that the enrichment is probably due to a relative accumulation of the phosphate which is primarily present in the rock. However, he also mentions the "guana theory" as a probably alternative or additional explanation for the phosphate accumulation of these rather young soils.

Finally, the work of a group of New Zealand soil scientists should be mentioned, which was recently published by Fieldes et al. (1961) concerning soils with low silicon contents, bigh phosphate contents (up to $14 \% \quad \mathrm{P}_{2} \mathrm{O}_{5}$ ) and also high radio activity, which were found on the coral limestone terraces of the Niue Islands. Without offering an explanation for the peculiar make-up of these soils, these investigators eiaborate the possible contamination of these limestone soils with volcanic and meteoric dust. Some aspects of their work will be dealt with later.

\subsection{A search for phosphorites}

Apart from the author's opinion, based on his present study, that the "guano theory" docs not deserve too much credit, it is quite evident that this theory never holds good for an area of more than 100.000 hectares of phosphatic soils. Therefore, an explanation for this surprising phenomenon was thought to be found, firstly, in the assumption that high phosphate content of the parent rock itself might cause the development of these phosphatic soils. Limestones often carry tricalcium phosphate to an extent ranging from a trace to as much as $80 \%$.

However, total analysis of 8 samples of parent rock that were available, did not confirm this first assumption. These limestone samples analyzed, as an average: $99,7 \% \mathrm{CaCO}_{3}$ and $0,20 \% \mathrm{P}_{2} \mathrm{O}_{5}$.

Nevertheless, the finding of such vast amounts of phosphatic soil was deemed to be of sufficient importance to request further investigation by geologists of the Government Bureau of Geology and Mining. In consequence, a geological survey 
was carried out in September 1959 by VAN DER WEgEN (1960) in the environment of Soroan (west of Ajamaroe) where highest phosphate contents of the soil had been previously analyzed. The main purpose of this survey was to ascertain whether high graded phosphatic limestones (phosphorites) could be discovered in the area. The world's phosphate deposits may be classified, roughly, as residual, replacement or sedimentary (CoLlings, 1949).

a. Residual phosphates, such as the Tennessee brown phosphates, are derived from beds of phosphatic limestone which form the substratum of this residual deposit.

b. Replacement phosphates of high grades are found in many Pacific islands, such as Ocean Isl., Naura Isl., Christmas Isl. etc. They are believed to be the product of the reaction of phosphatic solutions derived from bird guano with coral limestone. Although, normally, these phosphorites do not develop over large areas of 100.000 hectares their occurrence in the Ajamaroe region was not to be ruled out. In former years, small amounts of blackish phosphorite containing $31,5 \% \quad \mathrm{P}_{2} \mathrm{O}_{5}$, had been found on the tiny Pacific island of Ajawi, some $300 \mathrm{~km}$ north east from Ajamaroe (n.w. of Biak).

c. Sedimentary phosphate deposits are those that have accumulated as sediments and have later become interbedded with, usually, limestones and shales. In some cases beds of phosphatic limestones, which were formed in this way, have been raised above the surface of the sea and their phosphate content has concentrated still further through the leaching of their soluble carbonates. This type of phosphorite distinghuishes itself from other types by their great areal extent; so it seemed to fit best into the geomorphological picture of the Ajamaroe limestone region.

The investigations of the geological survey party yielded negative results as it was proved beyond doubt that phosphatic limestone, responsible for the formation of highly phosphatic soil, did not exist in the Ajamaroe region.

Though disappointing from an economic point of view, this negative conclusion stressed the importance of the finding from a pedological angle and referred the problem back to the field of soil research. Before presenting the author's further investigations, a summary will be given of the essential data on geology, morphoiogy and lithology of the area, as contained in the final survey report of the Government geologist VAN DER WEGEN (1960).

\section{Geological survey}

\subsection{General dat a}

The Ajamaroe limestone plateau, which is part of the stratigraphic "Kais-formation", has been formed by sedimentation or organic calcareous remains and abundant coral growth in a shallow, practically siltless sea of the Miocene era. In the surveyed area, we are dealing with poorly bedded, light coloured autochthonous limestones of (inter)biohermal character. The interbiohermal rock type is chalky and powdery on breakage. Its fossil content comprises mainly benthonic Foraminifera and Globegirina of the neritic zone. The interbedded biohermal limestones are, as a rule, harder and are composed of coarser organic remains with a preponderance of corals. The thickness of these limestones is estimated a few hundred metres.

Post-tertiary tectonic movements raised the plateau to its present elevation of 300 to $400 \mathrm{~m}$ above sea-level. Folding and faulting have produced an intersecting strong 
joint system with main directions NW-SE and NE-SW, which are clearly visible on the aerial photographs. Subsequent erosion and subterranean solution of the limestone resulted in the present karst morphology of the landscape with its conical shaped hills ("sugarloaf" topography; see FIG. 3), dolines, uvalas, poljes and underground drainage systems (FIG. 4). On the map (FIG. 1) the relative ruggedness of the landscape, as conditioned by the degree of karst development, is expressed in the three component areas $\mathrm{a}, \mathrm{b}$ and $\mathrm{c}$ of the actual karst landscape I. Area Ia is the most rugged and inaccessable one. Area $\mathrm{Ib}$ is far less dissected and forms part of a WNW-ESE striking syncline which descends towards the trough in landscape II with a gentle dip of less than $10^{\circ}$. The topography of the landscape Ic is intermediate between Ia and Ib.

\subsection{Fi eld work}

Samples of fresh limestone and earth were collected from three sites in the vicinity of the native settlement of Soroan.

Site $A$ was an abandoned peasant cocoa plot in an uvala, a few hundred metres west of Soroan across the rivulet "Sewarn". The uvala has a narrow entrance, is about $200 \mathrm{~m}$ long and $20-40 \mathrm{~m}$ wide, and is enclosed by steep limestone ridges of conical shaped hills about $50 \mathrm{~m}$ in height. In this spot 11 soil samples were collected from 7 auger holes and 3 limestone samples were taken from the hillside, one from the bottom part (G. 127), one from the middle (G. 128) and one near the top (G. 129) of the steep slope.

Site $B$ was situated about $2 \mathrm{~km}$ west of Soroan and also inside an uvala. Here, 9 soil samples were taken from 3 auger holes and 5 limestone samples were collected at regular interspaces along the slope of the bordering hill which was $55 \mathrm{~m}$ high. Sample G. 123 was the lower and G. 126 was th ehigher one.

Site $C$ was selected along the path leading to Ajamaroe, some $3 \mathrm{~km}$ away from Soroan, on a somewhat elevated plateau-like site in landscape Ib. Five soil samples were drawn from 3 auger holes and one limestone sample was taken from a nearby "sugarloaf" hill.

In TABLE 1, a presentation is given of sampling depth, the phosphate and iron contents of the soil samples and also of the phosphate and magnesium contents of the limestone samples.

Each soil sample was taken over the full length of the indicated sampling depth. The lower sample in each auger hole always reaches down to the parent rock.

\subsection{The limestone samples}

The magnesia percentage of the limestone is low in comparison with the average percentage of 7,90 for all limestones as computed by RANKAMA and SAHAMA (1949). The absence of dolomitisation, therefore, confirms that the Ajamaroe limestone must have been formed in a shelf-sea. The phosphate contents, which average $0,24 \%$ $\mathrm{P}_{2} \mathrm{O}_{5}$, are higher than the general average of $0,08 \% \quad \mathrm{P}_{2} \mathrm{O}_{5}$ computed by the aforementioned authors (RANKAMA and SaHAMA, 1949). The former average comes very close to the earlier mentioned average of $0,20 \% \quad \mathrm{P}_{2} \mathrm{O}_{5}$ that had been found for eight other limestone samples from the Ajamaroe area.

However, it should be noticed that the variation in phosphate content from site to site is relatively wide, ranging from $0,08 \%$ at the lowest to $0,36 \%$ at the highest.

There is faint tendency that samples lower down the hillsides contain more phosphate than the samples near the top. It may be an indication that enrichment with 


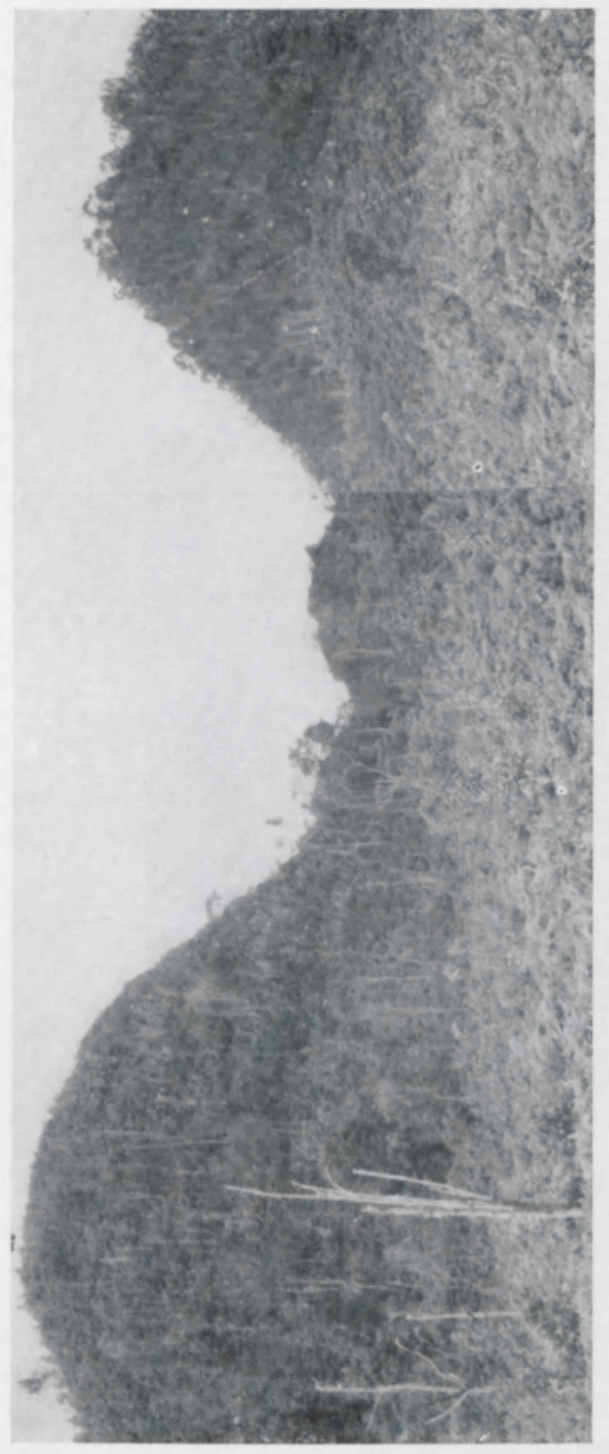

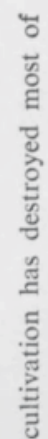

흥 竞

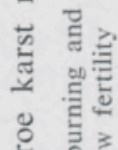

을 흐므

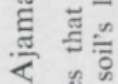

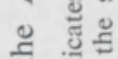

$\cong$.

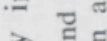

ลิ

해웡

요

i

으 응

공

की

कू

$\dot{m}$

ఏ் 


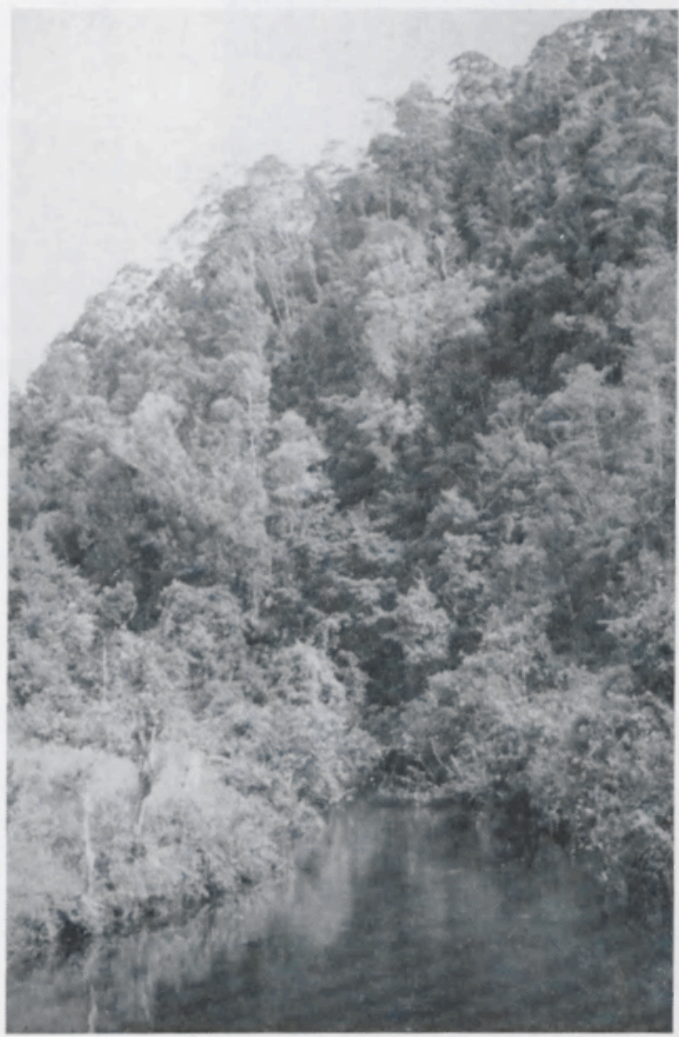

FIG. 4. Conical limestone hill with original forest vegetation Sewarn river in foreground emerges from a "ponor" at the other side of the hill 
A STUDY OF HIGHLY PHOSPHATIC SOILS IN A KARST REGION OF THE HUMID TROPICS

TABLE 1. Analyses of soil and limestone samples

\begin{tabular}{|c|c|c|c|c|c|c|c|c|}
\hline \multicolumn{6}{|c|}{ Soil samples } & \multicolumn{3}{|c|}{ Limestone samples } \\
\hline Site & $\begin{array}{l}\text { hole } \\
\text { No. }\end{array}$ & $\begin{array}{l}\text { sample } \\
\text { No. }\end{array}$ & $\begin{array}{l}\text { depth } \\
\text { (m) }\end{array}$ & $\underset{(\%)}{\mathrm{P}_{2} \mathrm{O}_{5}}$ & $\begin{array}{c}\mathrm{Fe}_{2} \mathrm{O}_{3} \\
(\%)\end{array}$ & $\begin{array}{l}\text { sample } \\
\text { No. }\end{array}$ & $\underset{(\%)}{\mathrm{P}_{2} \mathrm{O}_{5}}$ & $\begin{array}{l}\mathrm{MgO} \\
(\%)\end{array}$ \\
\hline A & $\begin{array}{l}\text { I } \\
\text { II } \\
\text { III } \\
\text { III } \\
\text { IV } \\
\text { IV } \\
\text { V } \\
\text { V } \\
\text { VI } \\
\text { VI } \\
\text { VII }\end{array}$ & $\begin{array}{l}\text { V. } 201 \\
\text { V. } 202 \\
\text { V. } 203 \\
\text { V. } 204 \\
\text { V. } 205 \\
\text { V. } 205 \\
\text { V. } 207 \\
\text { V. } 208 \\
\text { V. } 209 \\
\text { V. } 210 \\
\text { V. } 211\end{array}$ & $\begin{array}{l}0,0-0,67 \\
0,0-0,46 \\
0,0-1,00 \\
1,0-1,10 \\
0,0-1,00 \\
1,0-1,30 \\
0,0-1,00 \\
1,0-1,73 \\
0,0-1,00 \\
1,0-1,32 \\
0,0-1,00\end{array}$ & $\begin{array}{l}11,91 \\
12,70 \\
17,18 \\
15,81 \\
14,96 \\
14,98 \\
15,67 \\
16,64 \\
16,10 \\
16,33 \\
13,91\end{array}$ & $\begin{array}{l}13,76 \\
17,23 \\
15,22 \\
15,07 \\
16,58 \\
15,92 \\
16,96 \\
16,70 \\
17,91 \\
17,44 \\
15,93\end{array}$ & & & \\
\hline & & & & & & $\begin{array}{l}\text { G. } 127 \\
\text { G. } 128 \\
\text { G. } 129 \\
\text { G. } 110 \\
\text { G. } 120\end{array}$ & $\begin{array}{r}0,35 \\
0,21 \\
0,17 \\
-\end{array}$ & $\begin{array}{l}0,50 \\
0,59 \\
0,53 \\
0,78 \\
0,75\end{array}$ \\
\hline & & & Average for site $\mathbf{A}$ & 15,11 & 16,25 & & 0,24 & 0,63 \\
\hline B & $\begin{array}{l}\text { VIII } \\
\text { VIII } \\
\text { VIII } \\
\text { VIII } \\
\text { IX } \\
I X \\
X \\
X \\
X\end{array}$ & $\begin{array}{l}\text { V. } 212 \\
\text { V. } 213 \\
\text { V. } 214 \\
\text { V. } 215 \\
\text { V. } 216 \\
\text { V. } 217 \\
\text { V. } 218 \\
\text { V. } 219 \\
\text { V. } 220\end{array}$ & $\begin{array}{l}0,0-1,00 \\
1,0-2,00 \\
2,0-3,00 \\
3,0--3,18 \\
0,0-1,15 \\
1,05-1,90 \\
0,0-1,00 \\
1,0-2,00 \\
2,0-2,50\end{array}$ & $\begin{array}{l}21,39 \\
25,30 \\
26,25 \\
23,30 \\
19,36 \\
14,80 \\
20,83 \\
26,67 \\
28,02\end{array}$ & $\begin{array}{r}14,28 \\
10,59 \\
8,89 \\
8,72 \\
17,86 \\
10,65 \\
15,09 \\
9,55 \\
7,37\end{array}$ & & & \\
\hline & & & & & & $\begin{array}{l}\text { G. } 122 \\
\text { G. } 123 \\
\text { G. } 124 \\
\text { G. } 125 \\
\text { G. } 126\end{array}$ & $\begin{array}{l}0,34 \\
0,28 \\
0,11 \\
0,36 \\
0,08\end{array}$ & \\
\hline & & & Average for site $B$ & 22,44 & 11,50 & & 0,23 & \\
\hline C & $\begin{array}{l}\text { XI } \\
X I \\
X I I \\
\text { XIII } \\
\text { XIII }\end{array}$ & $\begin{array}{l}\text { V. } 221 \\
\text { V. } 222 \\
\text { V. } 223 \\
\text { V. } 224 \\
\text { V. } 225\end{array}$ & $\begin{array}{l}0,0-1,00 \\
1,0-1,66 \\
0,0-0,95 \\
0,0-1,00 \\
1,00-1,58\end{array}$ & $\begin{array}{l}1,30 \\
1,09 \\
0,93 \\
0,88 \\
0,90\end{array}$ & $\begin{array}{l}22,02 \\
17,68 \\
18,39 \\
16,67 \\
14,98\end{array}$ & $\pi+26$ & & \\
\hline & & & Average for site $\mathrm{C}$ & 1,02 & 17,90 & G. 136 & $\begin{array}{l}0,24 \\
0,24\end{array}$ & \\
\hline
\end{tabular}

Analyses carried out: Lab. Mining Dept. of the Technical High School, Delft, Netherlands.

phosphate took place through phosphate containing leacheate from upper limestone layers. However, this tendency may be a pure coincidence as well. In this respect it should be mentioned that e.g. samples G. 125 and G. 127 are found to be harder and richer in fossils than the other, which may account for their higher phosphate contents. A very important fact was the microscopic determination of tiny apatite crystalls in all of the 17 limestone samples examined. They must have been formed secundarily during the diagenesis of the limestone from primary organic sources. From the above data it may be concluded that phosphatic limestones do not occur 
in the investigated areas where highly phosphatic soil is found and that the actual phosphate contents of the limestones are very near normal.

\subsection{The soil s a mples}

The phosphate contents of the soil samples from the uvala-bottoms in site $A$ and $B$ are much higher than those in the sample site $C$. The soils of site $B$ reach a record of $28 \% \quad \mathrm{P}_{2} \mathrm{O}_{5}$ whereas samples of site $\mathrm{C}$ show a minimum for the area of slightly less than $1 \% \mathrm{P}_{2} \mathrm{O}_{5}$. We have already seen that the phosphate contents of the parent rock did not offer a direct clue to this striking difference. In sample site $B$ we find a slight indication that $\mathrm{P}_{2} \mathrm{O}_{5}$ percentages of subsequent soil layers increase lower down the profile. This tendency is not confirmed in sites $A$ and $C$.

The $\mathrm{Fe}_{2} \mathrm{O}_{3}$-contents of the soil samples do neither offer an explanation for differences in phosphate contents as there is no distinct connection between phosphate and iron percentages. In sample site $\mathbf{B}$ a noticeable drop in iron content takes place as the sampling depth increases, without showing a distinct negative correlation with increasing phosphate contents. It may be that ferro compounds are removed secundarily from the lower horizons due to moister condition. From the above data it appears that phosphate, derived from normal parent rock may accumulate up to hundred fold in its weathering product, the soil. This phosphate tends to be more or less evenly distributed throughout the soil profile. The variable degree of phosphate accumulation at different sites is not explained.

\subsection{Retrospective considerations}

For a proper understanding of the following pedogenetic investigations, the point should be stressed that, according to the conclusions of VAN DER WEGEN, the intricate landscape pattern of numerous hills and ridges, seperating or enclosing the multiform depressions, is a result of karst erosion. The arrangement of mounds and valleys is greatly conditioned by the original drainage pattern of the area that followed the main directions of the joint system. Dolines and uvalas are also more or less aligned along the cracks of the substrata, as here excessive drainage results in accelerated solution of the limestone rock.

These facts are confirmed by the topographic study of the Ajamaroe limestone region by PANNEKoEK (1941). The domes, ridges and pinnacles are the positive expression of a pronounced sink hole morphology. This implies that, locally, there is no essential lithographic difference to be expected between the limestone that dissolved and disappeared in the depressions and the limestone that is still existing in the surrounding hills. Consequently, it may be assumed that, in any restricted area, the phosphate contents of all limestone rock fluctuate around a certain local average, so that the average phosphate percentage of soil formed in depressions can be directly related to the average phosphate content of the adjacent limestone outcrops.

This aspect is mentioned on purpose, because there are limestone regions in which the topographical pattern is greatly conditioned by the primary qualitative differences of the limestone rock and by its varying resistance against erosion. In such cases, soils in depressions are derived from different types or phases of limestone rock than the soils on the slopes and plateaus. 


\section{Basic analytical data of a standard soil sample}

\subsection{The standard soil sample B. 6252}

For the need of further laboratory and greenhouse investigations, a large sample of soil with a high phosphate content was obtained through the agricultural officer in Ajamaroe. The sample was collected at sampling site B of the geological survey, somewhere between the auger holes IX and $\mathrm{X}$. This bulk sample was representative for the full soil depth from \pm 5 to $100 \mathrm{~cm}$. Its Munsell color was "reddish brown" (5 YR, 4/3) when moist and "brown" (71/2 YR, 5/4) when dry. After pulverizing and homogenizing, the whole bulk sample was registered under nr. B. 6252. The soil was tested in the greenhouse on its qualities as a fertilizer material. These results will be discussed in chapter 5 .

For the present, we are concerned in this chapter with the results of the various laboratory investigations which were to reveal particulars about the type, distribution and behaviour of the phosphate contained in this soil sample.

\subsection{Textural dat a}

According to the classification system of the U.S. Soil Survey Manual, which is used in this country, the soil could be denoted as a silty clay, containing 1,2\% sand, $50,1 \%$ silt and $48,7 \%$ clay.

The sand fractions were:

$$
\begin{array}{rr}
0,4 \% & 2000-500 \mathrm{mu} \\
0,4 \% & 500-210 \mathrm{mu} \\
0,4 \% & 210-50 \mathrm{mu} \\
0,1 \% & 50-16 \mathrm{mu} \\
50,0 \% & 16-2 \mathrm{mu}
\end{array}
$$

The silt fractions were: $\quad 0,1 \% \quad 50-16 \mathrm{mu}$

The texture analysis was carried out after the usual pre-treatment with $\mathrm{H}_{2} \mathrm{O}_{2}$ and diluted $\mathrm{HCl}$.

\subsection{Available phosphate}

The Truog method was used for the determination of available phosphate; the Truog value was 650 p.p.m. $\mathrm{P}_{2} \mathrm{O}_{5}$. This extraction $(2 \mathrm{~g}$ soil shaken for $30 \mathrm{~min}$ with $400 \mathrm{cc}$ 0,002 norm $\mathrm{H}_{2} \mathrm{SO}_{4}$ ) was repeated ten times.

The 2 grams of soil, separated and dried before each following exiraction, yielded $650,650,515,505,395,245,215,215$ and 210 p.p.m. This makes a total of $0,09 \%$ $\mathrm{P}_{2} \mathrm{O}_{5}$ that dissolved.

The same repeated extraction was carried out with $400 \mathrm{cc}$ distilled water. With this treatment the values $35,35,21,19,19,19,19,14,14$ and 14 p.p.m. were obtained, which makes a total of 210 p.p.m. or $0,02 \% \quad \mathrm{P}_{2} \mathrm{O}_{5}$.

From these data it may be concluded that the phosphate contained in the soil is fairly soluble and easily available to plants. However, its solubility is far too low to suggest the presence of monocalciumphosphate in the soil.

When the extraction was carried out with diminishing amounts of water, considerable less phosphate dissolved:

$2 \mathrm{~g}$ soil : $400 \mathrm{cc}$ water, recovery 35 p.p.m.

$2 \mathrm{~g}$ soil : $200 \mathrm{cc}$ water, recovery 21 p.p.m.

$2 \mathrm{~g}$ soil : $100 \mathrm{cc}$ water, recovery 11 p.p.m.

$2 \mathrm{~g}$ soil : $50 \mathrm{cc}$ water, recovery 6 p.p.m.

$$
\text { (p.p.m. }=\mathrm{mg} / \mathrm{kg} \text { soil) }
$$




\subsection{Removal of phosphate by leaching}

In order to obtain an estimate of the downward movement of dissolved phosphate in the soil profile under conditions of high rainfall, a percolation test was carried out in duplicate. To this end, a 50/50 mixture of quartz sand and $70 \mathrm{~g}$ of powdered, air-dried soil was loosely packed in a percolating tube. The column, occupied by this mixture, measured $20 \mathrm{~cm}$ in height with a cross area of $5 \mathrm{~cm}^{2}$. The density of $70 \mathrm{~g}$ of soil per $100 \mathrm{cc}$ volume thus obtained, corresponded with the specific density of the soil under natural undisturbed field conditions which proved to be 0,7 . Within a month's time, $450 \mathrm{cc}$ distilled water was percolated through. This quantity of water corresponds with a rainfall of $900 \mathrm{~mm}$, which is more than twice the average monthly rainfall of about $400 \mathrm{~mm}$ prevailing in the Ajamaroe region.

The total amount of phosphate recovered in the leacheate was only 20 gamma $\mathrm{P}_{2} \mathrm{O}_{5}$. For argument's sake we may assume that with half the amount of water used, not more than 10 gamma $\mathrm{P}_{2} \mathrm{O}_{5}$ would have been recovered.

This laboratory test suggests, that only 2 gamma $\mathrm{P}_{2} \mathrm{O}_{5}$ would have been removed from a soil layer of $20 \mathrm{~cm}$ high per $\mathrm{cm}^{2}$, during a monthly rainfall of $400 \mathrm{~mm}$. Within a year, 24 gamma $\mathrm{P}_{2} \mathrm{O}_{5}$ would have been removed under Ajamaroe rainfall conditions of $4800 \mathrm{~mm}$ per annum. From this calculation it follows that, within a thousand years, under the same conditions, only $24 \mathrm{mg} \mathrm{P}_{2} \mathrm{O}_{5}$ per $\mathrm{cm}^{2}$ would have been removed from the top $20 \mathrm{~cm}$ of soil, which means a loss of about $0,17 \%$ in this soil layer. This conclusion is of some importance in connection with the pedogenetic aspects of the present enigma. It proves that accumulation of phosphate in this soil is not caused by enrichment of lower horizons at the expense of the upper horizons.

\subsection{Total phosphate determinations}

The total phosphate content of the soil sample B. 6252 was determined (on an airdry basis) by three different methods: fusion with sodium carbonate, digestion with a mixture of nitric and hydrochloric acid and our standard method, which is an extraction with Fleischmann acid (i.e. conc. sulfuric and nitric acid 50,50). All three methods yielded practically the same result, i.e. $18,5 \pm 0,2 \% \mathrm{P}_{2} \mathrm{O}_{5}$.

In order to ascertain which textural fraction carried most of this phosphate, three separate phosphate determinations were carried out, which proved that the sand fraction contained 5,67 , the silt fraction 18,6 and the combined silt plus clay fraction $18,55 \% \quad \mathrm{P}_{2} \mathrm{O}_{5}$.

From these analyses it appeared that the phosphate was evenly distributed throughout the silt and clay fractions. The lower phosphate content of the very small sand fraction is attributed to its relatively high percentage of iron concretions which contain very little phosphate.

\subsection{The phosphate bearing compound (X)}

Earlier microscopical examination of the sand fractions of other Soroan soil samples with high phosphate content, had proved the absence in the soil of the phosphate bearing mineral apatite. However, a striking feature of these sand fractions was the presence of a fair percentage of greyish grains which were optically isotropic and stiggested the possible presence of an amorphous phosphatic compound resembling the secundary crypto-crystalline mineral collophane. With the aid of a binoculair, a small amount of these grains was hand-picked and separately analyzed. 
As this material contained as much as $21,8 \% \quad \mathrm{P}_{2} \mathrm{O}_{5}$, it proved indeed to be the main phosphate-bearing compound of the sand fractions.

Scanning in the same way, a weighed portion of the sand fraction $(2000-105 \mu)$ of sample B. 6252, our mineralogist succeeded in sub-dividing this portion, by visual judgement, into four main components: quartz $(Q)$, iron concretions $(F)$, the phosphatic yellowish compound $(\mathrm{X})$ and a mixture $(\mathrm{M})$. This mixture $(\mathrm{M})$ was composed of grains that could not be classified with certainty as either $(\mathrm{X})$ or $(\mathrm{F})$; they resembled iron-coated phosphatic grains (X).

The fractions $(\mathrm{X}),(\mathrm{F})$, and $(\mathrm{M})$ were analyzed quantitatively on the elements $\mathrm{Si}, \mathrm{P}$, $\mathrm{Ca}, \mathrm{Fe}$ and $\mathrm{Al}$. The results, expressed as oxides, are presented in TABLE 2.

TABLE 2. Analysis of four components of the sand fraction of sample B. 6252

\begin{tabular}{|c|c|c|c|c|c|c|c|}
\hline & & \multicolumn{6}{|c|}{ Percentages } \\
\hline & & $\mathrm{SiO}_{2}$ & $\mathrm{P}_{2 .} \mathrm{O}_{5}$ & $\mathrm{CaO}$ & $\mathrm{Fe}_{2} \mathrm{O}_{3}$ & $\mathrm{Al}_{2} \mathrm{O}_{3}$ & remainder \\
\hline $7,1 \%$ quartz & $(Q)$ & 100,0 & - & - & - & 一 & 0,0 \\
\hline $77,3 \%$ iron concretions & (F) & 2,1 & 2,9 & 1,8 & 63,6 & 6,3 & 23,3 \\
\hline $4,8 \%$ phosphatic grains & (X) & 3,6 & 23,4 & 8,7 & 9,2 & 26,8 & 28,3 \\
\hline $10,8 \%$ mixture $\ldots \ldots$ & (M) & 3,9 & 18,3 & 8,0 & 13,2 & 23,6 & 33,0 \\
\hline $\begin{array}{l}100 \% \text { sand fraction } \\
\text { composition calculated }\end{array}$ & & 14,6 & 5,3 & 2,7 & 51,0 & 8,7 & 17,7 \\
\hline
\end{tabular}

The analytical results confirm our presumption, that the mixture $(M)$ consists mainly of iron-coated phosphatic grains. Both fractions $(\mathrm{X})$ and $(\mathrm{M})$ are made up, apparently, of calcium, aluminium, iron and phosphate. Their low silica content should probably be regarded as an impurity rather than a true component of the phosphatic grains.

When considering the make-up of the phosphatic material $(\mathrm{X})$, its proportionate percentages (by weight) of the oxides $\mathrm{CaO}, \mathrm{P}_{2} \mathrm{O}_{5}, \mathrm{Al}_{2} \mathrm{O}_{3}$ and $\mathrm{Fe}_{2} \mathrm{O}_{3}$ are 8,7; 23,4; 26,8 and 9,2 respectively. When divided by their molecular weights, these four components show a molar ratio to each other of :

$$
\begin{aligned}
\mathrm{CaO}: \mathrm{P}_{2} \mathrm{O}_{5}: \mathrm{Al}_{2} \mathrm{O}_{3}: \mathrm{Fe}_{2} \mathrm{O}_{3} & =1,88: 2,00: 3,17: 0,80 \\
& =2: 2: 3: 1 \text { (approx.) }
\end{aligned}
$$

If we assume that only $\mathrm{CaO}$ and $\mathrm{P}_{2} \mathrm{O}_{5}$ combine in a molecular structure, leaving $\mathrm{Al}_{2} \mathrm{O}_{3}$ and $\mathrm{Fe}_{2} \mathrm{O}_{3}$ out as additional admixtures of the compound, only mono-calciumphosphate $\left(\mathrm{CaO}, \mathrm{P}_{2} \mathrm{O}_{5}, 2 \mathrm{H}_{2} \mathrm{O}\right)$ could form according to the above molar ratio.

The relatively low $\mathrm{CaO}$-content rules out the possibility of collophane as well. According to Rogers (1932) collophane forms in a medium which is rich in calcium, as its formula confirms :

$$
3 \mathrm{Ca}_{3}\left(\mathrm{PO}_{4}\right)_{2} \cdot \mathrm{n} \mathrm{Ca}\left(\mathrm{CO}_{3}, \mathrm{~F}_{2}, \mathrm{O}\right)\left(\mathrm{H}_{2} \mathrm{O}\right)_{\mathrm{x}}
$$

Considerable amounts of collophane also require a certain amount of Fluor, which requirement is not fulfilled by the Fluor percentage in TABLE 3 (total analysis).

The author is more inclined to assume that also most of the $\mathrm{Al}_{2} \mathrm{O}_{3}$ partakes in the molecular structure according to the above ratio $\mathrm{CaO}: \mathrm{P}_{2} \mathrm{O}_{5}: \mathrm{Al}_{2} \mathrm{O}_{3}=2: 2: 3$. This assumption would be in agreement with the formula of the secundary phosphate mineral Crandallite $\mathrm{Ca} \mathrm{Al} 3\left(\mathrm{PO}_{4}\right)_{2}(\mathrm{OH})_{6}$, which requires a composition of $2 \mathrm{CaO}$, $3 \mathrm{Al}_{2} \mathrm{O}_{3}, 2 \mathrm{P}_{2} \mathrm{O}_{5}, 6 \mathrm{H}_{2} \mathrm{O}$.

Very recently, attention was called by FiELDEs et al. (1961) to the fact that 


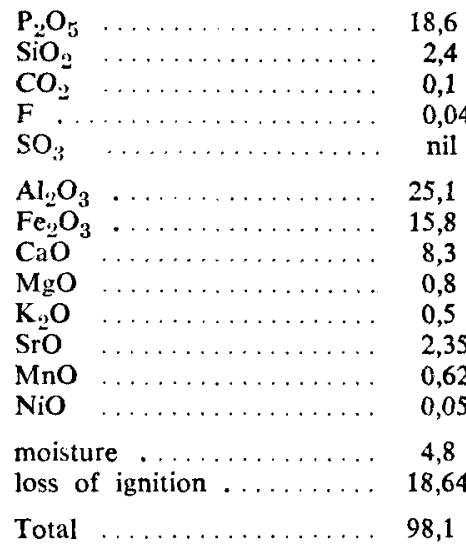

certain coral limestone soils in the S.E. Pacific with high phosphate contents, contain up to $40 \%$ Crandallite, which mineral is the main carrier of most of the calcium, aluminium and phosphorus present in such soils. It was found that $42 \%$ Crandallite corresponded with $14,4 \% \quad \mathrm{P}_{2} \mathrm{O}_{5}$. Crandallite is detectable by its X-ray diffraction pattern and also by its D.T.A. characteristics as described by NorRISH (1957).

\subsection{Total analysis of sample B. 6252}

A quantitative analysis of all elements present in soil B. 6252, was carried out in the Research Laboratory of the Albatros Superphosphate Works at Vlaardingen (Netherlands). The results, slightly modified and supplemented by the total analysis carried out in our Hollandia laboratory, are shown in TABLE 3. Traces of the elements As, $\mathrm{Cr}, \mathrm{Ti}, \mathrm{Zn}$ and $\mathrm{Y}$ were identified through $\mathrm{X}$-ray spectroscopy, whereas the presence of haematite could be ascertained in the same way.

It is interesting to observe that the percentages of the major components $\mathrm{CaO}, \mathrm{Al}_{2} \mathrm{O}_{3}$, $\mathrm{Fe}_{2} \mathrm{O}_{3}, \mathrm{P}_{2} \mathrm{O}_{5}$ and $\mathrm{SiO}_{2}$, as presented in TABLE 3, are practically identical with the percentages found for these same components in the analysis of mixture (M), i.e. the iron-coated phosphatic grains as follows from TABLE 4.

From this comparison it seems justified to conclude that most of the soil consists of iron-coated tiny particles of the phosphate bearing compound (X) that might be Crandallite.

TABLE 4. Quantitative analyses of soil sample B. 6252 and of component $M$

\begin{tabular}{lccccc} 
& \multicolumn{5}{c}{ Percentages } \\
\cline { 2 - 6 } & $\mathrm{CaO}$ & $\mathrm{Al}_{2} \mathrm{O}_{3}$ & $\mathrm{Fe}_{2} \mathrm{O}_{3}$ & $\mathrm{P}_{22} \mathrm{O}_{5}$ & $\mathrm{SiO}_{2}$ \\
soil sample B. $6252 \ldots \ldots \ldots \ldots \ldots \ldots$ & 8,3 & 25,1 & 15,8 & 18,6 & 2,4 \\
mixture $(\mathrm{M})$ in sand of sample B. 6252 & 8,0 & 23,6 & 13,2 & 18,3 & 3,9 \\
\hline
\end{tabular}

\subsection{Sum mary of results}

Summarizing the results of the above investigations, it can be stated that:

a. the high phosphate content of the soil is evenly distributed over the various textural fractions, with the exception of the very small sand fraction, which contains larger amounts of iron concretions; 
b. the iron concretions are very poor in phosphate which seems to indicate that phosphorus does not combine with iron in this soil to any significant extent;

c. because of the typical low silicon content, it is most likely that silicate clays are almost absent in this soil; its bulk virtually must consist of the phosphatic material itself, stained or coated with iron oxide;

d. on account of the molar ratio between the main components, in particular between calcium and phosphorus, it is more or less ruled out that apatite or collophane could form in this soil; the low Fluor content seems to confirm this;

e. the relatively low calcium content would allow only for the formation of monocalciumphosphate. This possibility must be rejected, because $\mathrm{Ca}\left(\mathrm{H}_{2} \mathrm{PO}_{4}\right)_{2}$ is far more soluble in water than appeared from our solubility tests;

f. on the strength of evidence obtained elsewhere and also on account of our own analytical data, it is most likely that the phosphatic compound is the secondary mineral Crandallite which comprises most of the calcium, aluminium and phosphorus present in this soil;

g. the occurrence of $2,35 \%$ SrO suggests a partial isomorphous replacement of calcium by strontium, as has been reported to happen in Crandallite by NoRkisH (1957).

\section{Supplementary investigations in field and laboratory}

In an attempt to clarify certain unsolved questions concerning the pedogenetic aspects of Ajamaroe soil formation, the region was visited once more by the author. Various soil profiles with underlying parent rock were sampled and, subsequently, analyzed in a search for additional information as to the actual character and mode of the phosphate accumulating process.

\subsection{Soil formation in dolines}

Considering a doline which is entirely encircled by a high wall of serried limestone hills, the soil found at the bottom of such a doline must be exclusively formed as a relict of the limestone that dissolved on the spot during bygone eras.

In addition, soil formed on the surrounding hillsides, and washed down the slopes during heavy downpours, must have contributed substantially to soil development in the doline. It is for this reason that soils formed in depressions are deeper than those that develop on flat limestone plateaus. As the parent rock in the deepening doline and on the surrounding hillsides is essentially the same, it follows that the chemical composition of the soil in a doline will not show great variations in vertical or horizontal direction. A certain degree of discontinuity in chemical and textural composition may show up in the soil profile, due to:

a. slight local variations in the composition of the dissolved limestone strata;

b. the segregating effect of flooding and subsequent sedimentation;

c. secundary alterations in the profile as a result of pedogenetic progress.

In TABLE 5, some analytical data of such a profile are presented. The samples were taken from a soil pit that was dug in the centre of a rather small but very deep doline, quite near the uvala of sample site $\mathbf{A}$. The place was enclosed by six steep domes of about $70 \mathrm{~m}$ high; the lowest entrance was along a saddle at a level of $30 \mathrm{~m}$ above the bottom of the doline. 
TABle 5. Analytical data of six layers of a doline soil profile

\begin{tabular}{|c|c|c|c|c|c|c|c|}
\hline Sample No. & V. 2 & V. 3 & V. 4 & V. 5 & V. 6 & V. 7 & Mean \\
\hline Sampling depth $(\mathrm{cm})$ & $0-10$ & $10-20$ & $20-35$ & $35-50$ & $70-85$ & $85-115$ & $0-115$ \\
\hline Munsell Color (moist) & $\begin{array}{c}71: \mathrm{YR} \\
3 / 2\end{array}$ & $\begin{array}{c}5 \text { YR } \\
3 / 4\end{array}$ & $\begin{array}{c}7\lfloor\mathrm{YRR} \\
4 / 4\end{array}$ & $\begin{array}{c}71 / 2 \mathrm{YR} \\
5 / 4\end{array}$ & $\begin{array}{l}71 / 2 Y R \\
5 / 6\end{array}$ & $\begin{array}{l}5 Y R \\
4 / 4\end{array}$ & \\
\hline $\begin{array}{c}\text { Texture } \\
\begin{array}{l}\text { sand } \% \\
\text { silt } \%\end{array} \quad \ldots \ldots \ldots \ldots \ldots \ldots \ldots \\
\text { clay } \% \\
\%\end{array}$ & $\begin{array}{r}9,1 \\
80,9 \\
10,0\end{array}$ & $\begin{array}{r}9,0 \\
58,2 \\
32,8\end{array}$ & $\begin{array}{r}5,6 \\
22,3 \\
72,1\end{array}$ & $\begin{array}{r}5,4 \\
20,5 \\
74,1\end{array}$ & $\begin{array}{r}4,5 \\
16,1 \\
79,4\end{array}$ & $\begin{array}{r}7,3 \\
14,6 \\
78,1\end{array}$ & $\begin{array}{r}6,8 \\
35,4 \\
57,7\end{array}$ \\
\hline $\begin{array}{l}\text { Name } \ldots \ldots \ldots \ldots \ldots \ldots \\
\text { Soil reaction }\end{array}$ & siit & $\begin{array}{l}\text { si. cl. } \\
\text { loam }\end{array}$ & clay & clay & clay & clay & clay \\
\hline $\begin{array}{ll}\mathrm{pH} & \left.\mathrm{H}_{2} \mathrm{O}\right) \\
\mathrm{pH} & (\mathrm{KCl})\end{array}$ & $\begin{array}{l}5,95 \\
5,70\end{array}$ & $\begin{array}{l}6,10 \\
5,55\end{array}$ & $\begin{array}{l}7,15 \\
5,85\end{array}$ & $\begin{array}{l}7,30 \\
5,85\end{array}$ & $\begin{array}{l}7,50 \\
5,80\end{array}$ & $\begin{array}{l}7,55 \\
6,00\end{array}$ & $\begin{array}{l}6,9 \\
5,8\end{array}$ \\
\hline $\begin{array}{l}\text { Phosphate content } \\
\text { (on oven-dry basis) } \\
\text { Total } \mathrm{P}_{2} \mathrm{O}_{5} \% \quad \ldots . . . . . \\
\text { Available } \mathrm{P}_{2} \mathrm{O}_{5} \text { p.p.m. (Truog) }\end{array}$ & $\begin{array}{l}15,0 \\
870\end{array}$ & $\begin{array}{r}16,5 \\
540\end{array}$ & $\begin{array}{l}17,6 \\
980\end{array}$ & $\begin{array}{l}17,5 \\
1030\end{array}$ & $\begin{array}{l}18,5 \\
1180\end{array}$ & $\begin{array}{l}17,9 \\
1140\end{array}$ & $\begin{array}{c}17,1 \\
950\end{array}$ \\
\hline
\end{tabular}

si. cl. denotes silty clay.

The loose, friable, organic top layer (V. 2) and the underlying transitional layer (V. 3) are both eluvial horizons, as follows from the analyses. A real textural B-horizon was not apparent, probably, because the soil has a very porous structure with excellent internal drainage so that most of the clay from the eluvial horizon has been evenly distributed throughout the soil beneath $20 \mathrm{~cm}$ depth.

4.2. Soil from the hillsides

As a point of interest, the author wants to express his opinion that hillside erosion and subsequent wash of hillside soil into the doline, may occur in a substantial way mainly during the earlier stages of karst development. Inspecting the doline during a very heavy and prolonged rainstorm, it was observed that very little water ran down the slopes of the surrounding domes. Though densely forested up to their crests, the hills carry only a thin soil layer of $\pm 20 \mathrm{~cm}$ on the lower part of the slopes. Here, the slope is not too steep and a mixture of yellowish brown soil and grit of limestone, consolidated by numerous roots, covers the cracked and porous rock. On this part of the hillside there is a slow but steady wash along the slope and down into the limestone. The upper part, which sometimes takes up as much as two thirds of the slope, is very steep and carries hardly any soil. Locally, in sheltered spots, a few centimetres of highly organic blackish soil is found lying on and between white limestone. This shallow soil resembles a Rendzina. Near the crest, the highly cavernous limestone core, which looks more like a loose pile of blocks, is covered only by a very thick fibrous layer of roots without soil. Most of the rock surface underneath is self-cleaning. Therefore, once this type of karst has reached this advanced stage of development, most rainwater will go straight down into the interior of the hills, rushing through a maze of cracks, crevices and holes towards the subterranean drainage system of the area.

\subsection{Soil formation in uvalas}

Uvalas are formed by the coalescence of two or more dolines. Therefore, soil formation in uvalas should be identical with soil development in dolines, provided that the uvala is enclosed by limestone hills. The Soroan uvala (sampling site A) is open 
on the side towards the Sewarn river. It seems most likely, that this uvala primarily formed as a flood valley of a small tributary of the Sewarn during the earlier stages of karst development. After subsidence of this tributary into the underlying limestone strata, the remaining valley developed further into an uvala by forming two shallow dolines, which are now seperated by a very low partition wall of cavernous limestone. When formed in this way, uvalas will initially develop soils of a mainly allochthonous character. The bulk of the soil profile must have been built up by erosion material from the surrounding area. Although the chemical composition of such profiles may be fairly constant, textural irregularities in the profiles are to be expected.

In the Soroan uvala, near the former auger hole A/IV (TABLE 1) a soil pit was dug and samples were taken from subsequent soil layers of $15 \mathrm{~cm}$ thickness. At a depth of $105 \mathrm{~cm}$ an irregular shaped outcrop of limestone rock was unearthed, showing an almost horizontal, rounded water hole of an approximately $20 \mathrm{~cm}$ diameter. This finding suggest the former flow of water in the uvala in a longitudal direction. In TABLE 6, analytica! data of these samples are presented, They demonstrate the discontinuity in texture, $\mathrm{pH}$ and Munsell colours which does not fit into the picture of a normal residual soil. Therefore, it is the more surprising that the

TABLE 6. Analytical data of seven layers of an uvala soil profile

\begin{tabular}{|c|c|c|c|c|c|c|c|c|}
\hline Sample No. & V. 12 & V. 13 & V 14 & V. 15 & V. 16 & V. 17 & V. 18 & Mean \\
\hline Sampling depth $(\mathrm{cm})$ & $0-15$ & $15-30$ & $30-45$ & $45-60$ & $60-75$ & $75-90$ & $90-105$ & $0-105$ \\
\hline $\begin{array}{l}\text { Munsell Color (moist) } \\
\text { Texture }\end{array}$ & $\begin{array}{c}5 \mathrm{YR} \\
3 / 3\end{array}$ & $\begin{array}{l}5 \mathrm{YR} \\
3 / 4\end{array}$ & $\begin{array}{c}71 / \mathrm{YR} \\
4 / 4\end{array}$ & $\begin{array}{l}5 \mathrm{YR} \\
5 / 6\end{array}$ & $\begin{array}{l}5 \mathrm{YR} \\
5 / 8\end{array}$ & $\begin{array}{c}7 / / 2 Y R \\
5 / 6\end{array}$ & $\begin{array}{c}71 / 2 \mathrm{YR} \\
5 / 8\end{array}$ & \\
\hline 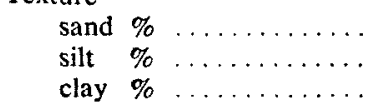 & $\begin{array}{r}8,8 \\
76,7 \\
14,5\end{array}$ & $\begin{array}{r}6,5 \\
51,8 \\
41,7\end{array}$ & $\begin{array}{r}3,7 \\
20,6 \\
75,7\end{array}$ & $\begin{array}{l}15,9 \\
45,8 \\
38,3\end{array}$ & $\begin{array}{r}8,4 \\
37,9 \\
53,7\end{array}$ & $\begin{array}{r}5,0 \\
37,0 \\
58,0\end{array}$ & $\begin{array}{r}5,8 \\
42,1 \\
52,1\end{array}$ & $\begin{array}{r}7,7 \\
44,5 \\
47,8\end{array}$ \\
\hline $\begin{array}{l}\text { Name } \ldots \ldots \ldots \ldots \ldots \\
\text { Soil reaction }\end{array}$ & $\begin{array}{l}\text { silty } \\
\text { loam }\end{array}$ & $\begin{array}{l}\text { silty } \\
\text { clay }\end{array}$ & clay & $\begin{array}{l}\text { si. cl. } \\
\text { loam }\end{array}$ & clay & clay & $\begin{array}{l}\text { silty } \\
\text { clay }\end{array}$ & $\begin{array}{l}\text { silty } \\
\text { clay }\end{array}$ \\
\hline $\begin{array}{l}\mathrm{pH}\left(\mathrm{H}_{2} \mathrm{O}\right) \\
\mathrm{pH}(\mathrm{KCl})\end{array} \ldots \ldots \ldots \ldots \ldots$ & $\begin{array}{l}5,55 \\
5,15\end{array}$ & $\begin{array}{l}6,50 \\
5,50\end{array}$ & $\begin{array}{l}7,30 \\
6,05\end{array}$ & $\begin{array}{l}6,40 \\
6,00\end{array}$ & $\begin{array}{l}6,45 \\
6,25\end{array}$ & $\begin{array}{l}6,50 \\
6,15\end{array}$ & $\begin{array}{l}6,70 \\
6,45\end{array}$ & $\begin{array}{l}6,5 \\
5,9\end{array}$ \\
\hline $\begin{array}{l}\text { Phosphate content } \\
\text { (oven-dry basis) } \\
\text { Total } \mathbf{P}_{2} \mathbf{O}_{5} \% \ldots \ldots \\
\text { Available } \mathbf{P}_{2} \mathbf{O}_{5} \text { p.p.m. . . . . }\end{array}$ & $\begin{array}{c}12,75 \\
650\end{array}$ & $\begin{array}{l}14,37 \\
620\end{array}$ & $\begin{array}{c}15,83 \\
890\end{array}$ & $\begin{array}{c}16,60 \\
530\end{array}$ & $\begin{array}{c}15,33 \\
530\end{array}$ & $\begin{array}{c}14,39 \\
750\end{array}$ & $\begin{array}{l}15,70 \\
1090\end{array}$ & $\begin{array}{r}15,0 \\
720\end{array}$ \\
\hline
\end{tabular}

si. cl. denotes silty clay.

phosphate contents of the different soil layers are more or less the same. The top layer (V. 12) shows the lowest value, probably due to some secondary leaching of the phosphate by organic solvents. The eluvial character of this top layer is also apparent from its lower clay content and its lower $\mathrm{pH}$. The homogenity of the phosphate content throughout the soil profile could only mean, that all limestone in the vicinity eventually produce a soil with the same average phosphate content.

4.4. Relationship between the phosphate in soil and 1 imestone

4.4.1. Uvala bottom soil

An analysis of a sample (V. $10 \mathrm{c}$ ) of the white limestone outcrop in the aforesaid 
profile revealed a phosphate content of $0,08 \%$. Its uppermost, brownish, somewhat weathered surface layer of approximately $1 \mathrm{~cm}$ was sampled seperately $(\mathrm{V} .10 \mathrm{~b}$ ) and proved to contain $0,16 \% \mathrm{P}_{2} \mathrm{O}_{5}$, which is twice the primary percentage. A thin soil layer of $1 \mathrm{~cm}$, resting immediately on top of the brownish limestone surface and stuck to it, was carefully collected (V. 10 a) and analyzed, showing a phosphate content of $8,38 \%$. Although it is not absolutely certain that this thin soil layer actually developed from the underlying rock, it still looked very much so. Assuming that soil and rock really belonged together, the analyses suggest that all phosphate contained in the fresh rock has been retained in its residue - the soil - after the rock dissolved. The concentration of $\mathrm{P}_{2} \mathrm{O}_{5}$ thus obtained in the thin soil layer is a hundred fold of the phosphate concentration in the fresh limestone. From this it follows, that the weight of the residue, including all the phosphate, must be one hundredth of the original weight of limestone that dissolved. Thus, it may be said, that the phosphate percentage of the soil will become higher as less residue is left behind after the rock has dissolved.

The fact that the bulk of the soil in this profile shows an average of $15 \% \quad \mathrm{P}_{2} \mathrm{O}_{5}$, could be explained by the assumption that the process of relative accumulation of phosphate in the lowest thin soil layer (V. 10 a) was not yet completed.

\subsubsection{Uvala hillside soils}

In order to find out whether the relationship between the phosphate contents of soil and parent rock was more or less the same in the surrounding hills and, also, in order to check whether hillside soils yielded phosphate contents of about $15 \%$, samples were taken in the Soroan uvala on the surrounding hillsides. These samples left no doubt that soil and parent rock really belonged together. The soil samples were composed of soil and grit of weathered limestone. Afterwards, these two components of the shallow soil layers were segregated in the laboratory for further analysis. The results are shown in TABLE 7 .

TABLE 7. Total phosphate content (\%) of five hill-side samples (on oven-dry basis)

\begin{tabular}{|c|c|c|c|c|c|}
\hline $\begin{array}{l}\text { Sample No. } \\
\text { Level }\end{array}$ & $\begin{array}{l}\text { V. } 10 \\
\text { zero }\end{array}$ & $\begin{array}{r}V .20 \\
+20 \mathrm{~m}\end{array}$ & $\begin{array}{r}V .23 \\
+25 \mathrm{~m}\end{array}$ & $\begin{array}{r}\text { V. } 24 \\
+50 \mathrm{~m}\end{array}$ & $\begin{array}{r}V .22 \\
+60 \mathrm{~m}\end{array}$ \\
\hline $\begin{array}{lll}\text { Soil } & \text { (a) } & \ldots\end{array} \ldots$ & $\begin{array}{l}8,38 \\
0,16\end{array}$ & $\begin{array}{l}7,68 \\
0,40\end{array}$ & $\begin{array}{l}9,21 \\
0,30\end{array}$ & $\begin{array}{l}2,80 \\
0,24 \\
0,15\end{array}$ & $\begin{array}{l}2,05 \\
0,22\end{array}$ \\
\hline
\end{tabular}

Sample V. $10 \mathrm{abc}$ is included in this table for the sake of comparison. Samples V. $20 \mathrm{abc}$ and V. $22 \mathrm{abc}$ were collected on the same hillside but at different heights above the uvala bottom. The same holds for samples V. 23 abc and V. 24 abc. Sample V. 22 a is a Rendzina-like soil, whereas sample V. 24 a represents a type that is intermediate by appearance between a Rendzina and the common (yellowish) brown soil type of the lower sampling places.

The analyses reveal that:

- phosphate contents of the limestone grits are about twice the phosphate contents of the corresponding fresh limestones. Although this finding is in accordance with the phosphate increase in sample V. $10 \mathrm{~b}$, it should not be considered a fixed rule that the first product of disintegration and weathering should contain exactly twice the amount of phosphate of the fresh parent rock; variations in the degree 
of disintegration and weathering will modify this first step of relative phosphate accumulation in the limestone grit;

- the sudden large increase in the phosphate content of the soil, as compared with the phosphate contained in the grit, also proved an undeniable fact that is confirmed by many other analyses;

- the lower hillside soils show phosphate contents of about $8 \%$, which is in agreement with the percentage found in the thin soil layer V. $10 \mathrm{a}$, this low percentage is against our expectations of values around $15 \% \quad \mathrm{P}_{2} \mathrm{O}_{5}$;

- the phosphate contents of the soils from the higher sites are still lower, showing a level of only 2 to $3 \% \quad \mathrm{P}_{2} \mathrm{O}_{5}$.

When leaving aside these last mentioned samples from the higher parts of the limestone domes, which develop under very special circumstances, we are still confronted with the problem why soils on the lower hillsides contain about $8 \% \quad \mathrm{P}_{2} \mathrm{O}_{5}$ whereas the uvala bottom soil average $15 \% \mathrm{P}_{2} \mathrm{O}_{5}$.

It is the author's firm belief that this disparity is due to the juvenile stage of the shallow hillside soils, which are a recent product of disintegration and weathering of the limestone grit they contain in their matrix. The hillside soils are sandy to silty loams with a low clay content. In the course of time the sand and silt particles will disintegrate and dissolve further, whereby these soils will relatively gain in clay and phosphate contents. It is almost certain that the hillside soils, contrary to the soils at the bottom of dolines and uvalas, will never reach this ultimate stage of maturity, being continuously rejuvenated by losing clay through wash.

\subsubsection{Other sampling places}

Evidence obtained in other places of the Ajamaroe region indicates that, outside enclosed dolines or uvalas, the phosphate content of the soil shows little connection with the present topographic environment of the sampling sites. The pureness and the phosphate content of the limestone seem to be the overruling factors.

When we recall the plateau-like sample site $C$ (TABLE 1), the soil from inree auger holes averaged only $1,02 \% \mathrm{P}_{2} \mathrm{O}_{5}$.

A limestone sample, actually retrieved by the author from the original auger hole C/XIII, proved to have an extremely low phosphate content of $0,01 \%$. This was a much lower level than that of the limestone sample G. 136 with $0,24 \% \mathrm{P}_{2} \mathrm{O}_{5}$ which was collected by the geologist from an adjacent limestone hill. On plateaus like this one, the phosphate content of the limestone may probably vary considerably from spot to spot.

In the Fatase area, the author found a very high phosphate content of about $29 \%$ throughout the soil of a pit which was dug on an open, flat limestone plateau that dominated the surroundings. The underlying limestone, found at $75 \mathrm{~cm}$ depth, proved to contain $0,66 \% \quad \mathrm{P}_{2} \mathrm{O}_{5}$.

Likewise, in a forested, rather level terrain NE of Fatase, the soil was $60 \mathrm{~cm}$ deep and contained $12 \% \quad \mathrm{P}_{2} \mathrm{O}_{5}$ as an average, whereas its limestone substratum was analyzed to contain, $0,42 \% \quad \mathrm{P}_{2} \mathrm{O}_{5}$.

In a freshly cut road traverse near Wok, a sample was taken from soil that had formed inside a horizontal crevice in the limestone, some two feet below the surface of the field; this soil was really autochthonous and contained $21,5 \% \quad \mathrm{P}_{2} \mathrm{O}_{5}$, whereas the underlying limestone proved to have a very high phosphate content of $0,70 \%$ $\mathrm{P}_{2} \mathrm{O}_{5}$. 


\subsection{General principles of phosphate accumulation}

Looking upon this enigma of highly phosphatic soils in a regional way, its complexity seems rather unsoluble. It is evident that the great diversity of topographic environment, erosion, vegetation, composition of rock and its primary phosphate content, which are involved in the process of soil formation, must cause inevitably a wide range of phosphate levels to be found in soils of this very rough karst landscape. However, on account of facts and considerations which hitherto were discussed, a limited number of principle rules can be brought forward which seem to determine, by themselves or in combination, the actual phosphate content of these limestone soils in each individual case.

We may summarize these principle rules as follows:

1. Relatively high phosphate contents of the fresh limestone tend to cause higher phosphate percentages in the soils.

Because large amounts of limestone must dissolve in order to obtain a certain amount of soil, a small rise of the $\mathrm{P}_{2} \mathrm{O}_{5}$-percentage in the limestone is greatly magnified. If, for instance, a limestone with $0,20 \% \quad \mathrm{P}_{2} \mathrm{O}_{5}$ yields a soil with about $8 \% \quad \mathrm{P}_{2} \mathrm{O}_{5}$, it is conceivable that under similar conditions a limestone with $0,50 \% \quad \mathrm{P}_{2} \mathrm{O}_{5}$ could form a soil with about $20 \% \mathrm{P}_{2} \mathrm{O}_{5}$.

2. Limestones with a relatively low percentage of insoluble residue tend to form soils with higher $\mathrm{P}_{2} \mathrm{O}_{5}$ percentages.

The smaller the percentage of insoluble residue that becomes "soil" and contains the liberated phosphate, the higher its phosphate content expressed as a percentage will rise. Here again, it should be appreciated that relatively small variations of the percentage of residue will have a large effect because of the multiplication factor. The pure reef limestones are the ones that will produce soils with high phosphate contents, whereas argillaceous limestones do not have this inherent property.

3. The more the weight of soil which is formed from a certain weight of rock is increased by accumulating elements other than phosphate, the lower the phosphate percentage tends to be.

"Soil" is formed from the insoluble residue but also from elements, such as calcium, iron and aluminium, which are soluble but are retained in the solum because they form insoluble compounds on their own or in combination with phosphorus. For instance, if large amounts of iron accumulate in a certain soil layer, the specific weight of the soil increases and a certain weight of this soil will contain less phosphate, i.e. a lower percentage of $\mathrm{P}_{2} \mathrm{O}_{5}$ is analyzed.

4. Immature soils that still possess the potential to loose weight through solution and leaching of its constituents other than phosphate, tend to have lower phosphate contents than mature soils.

An example of this rule is the immature hillside soil type.

5. Losses of phosphate during or after completion of the soil-forming process may diminish the phosphate percentage of the soil.

Organic solvents contained in the percolating rain water seems to move phosphate from the topmost eluvial horizon into the sub soil in the course of ages.

6. Gains of phosphate in illuvial soil horizons increase the phosphate percentage of such horizons. 
This rule is the reverse of the previous one; there is a general tendency that phosphate percentages increase slightly with depth of soil, whereas, near the parent rock deeper down into the profile the phosphate percentages tend to decrease because of rule nr. 4.

\subsection{The quantitative relation between soil and dissolving limestone}

The large amounts of limestone rock that must dissolve in order to create a certain layer of soil, have puzzled many investigators of "terra rossa" and similar soils. According to HARRISON (quoted by MOHR and VAN BAREN (1959) who studied the weathering of coral rock in Barbados, $1 \mathrm{~m}$ of soil is believed to be formed at the expense of $150 \mathrm{~m}$ of rock. Elsewhere in the world, it has been proved that the weathering product of limestone has often been extensively contaminated with minerals of volcanic origin, indicating that volcanic ashes may have contributed substantially to the building-up of these soils. Likewise, additions of meteoric dust have been suggested in this respect. Although these additions from the aerosphere may help to explain the accumulation of an element like iron, it is hardly conceivable that these additions may account in any way for the impressive accumulations of phosphate. In our case, the theory of volcanic dust has not been confirmed by mineralogical analyses, whereas the quantitative relation between soil and dissolved rock is not in need of additions from outside the lithosphere. If we assume that the phosphate concentration in the soil is exclusively the result of relative accumulation of phosphate contained in the parent rock, it is the ratio between phosphate percentages in soil and rock, combined with the specific weights of both materials, that provides a means to estimate the aforesaid ratio.

In TABLE 8 such an estimate is presented for two different samples from Fatase and Wok. The calculation is self-explanatory. The specific weight of the soil was measured in its natural and undisturbed position, by means of the ring-sampling method. For the sake of comparison, all phosphate contents of limestone and soil samples were determined (on an oven-dry basis) by extracting the samples with a boiling mixture of nitric and chloric acid. In the table a general example, based on averaged data, is also included.

From these calculations it follows that, starting from a fixed phosphate percentage in the limestone, more rock has to dissolve if the phosphate content of the soil is higher, and/or, the specific weight of the soil is greater. On the other hand, it follows that the higher the phosphate content and/or the specific weight of the limestone, the less of this rock will have to dissolve in order to obtain a certain volume of soil with a certain phosphate content.

It appears, that as a maximum, not much more than $75 \mathrm{~m}$ of limestone have to dissolve to obtain $1 \mathrm{~m}$ of soil.

The average height of domes and ridges is somewhere between 60 and $70 \mathrm{~m}$ above the level of sinkhole bottoms in the Ajamaroe region.

We may conclude this paragraph with the remark that in a rough tropical karst landscape with abundant rainfall like that of the Ajamaroe region, present magnitudes of soil layers do not always have a simple relation to underlying rock that vanished in the course of time. We pointed out that in dolines a funnel-shaped volume of limestone is actually involved when considering the soil layer at the bottom of a doline. On the other hand, when dealing with plateau-like areas, we are not always sure whether inversion of the topography may have taken place 


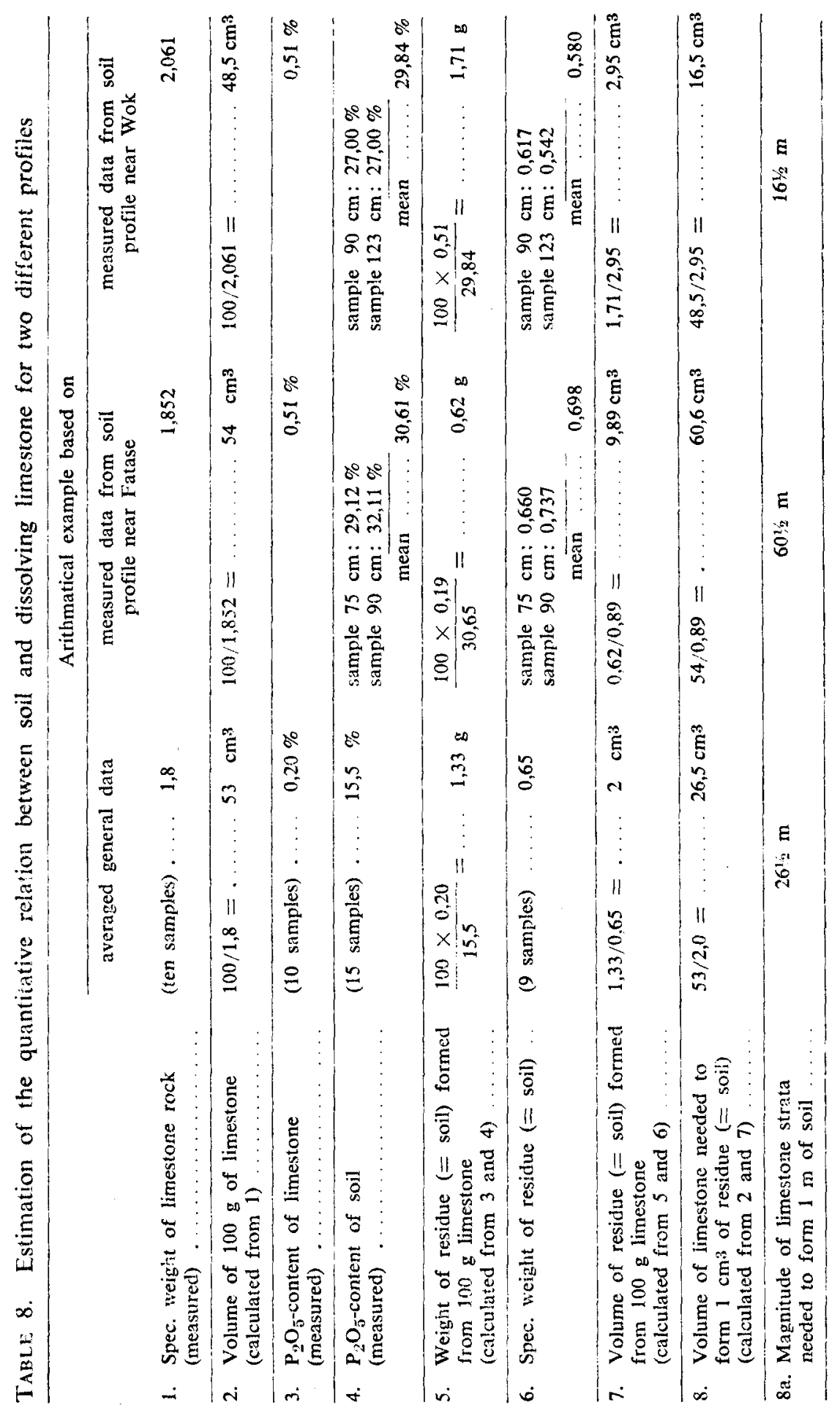


in the course of ages and, accordingly, the plateau soil has been built-up in a former depression.

\section{Occurrence and use of phosphatic limestone soils}

\subsection{Occurrence in West $\mathrm{New} G u$ inea}

Once the Ajamaroe type of highly phosphatic soils were discovered, subsequent soil surveys brought to light that in karst regions with pure, biohermal limestones, this soil type may be encountered in variable degrees of maturity.

On the elevated sub-recent (pleistocene) reef-plateaus in the southern part of the island Biak, phosphatic soils occur in large areas with young karst topography. In his soil survey report, RAzOUX SCHULTZ (1959) describes two major phases of a silty clay on limestone, occurring in the Biak-Siabes area (15.000 ha) and the Sorian area (2.000 ha). Our routine analyses of the chemical composition of the "yellowish brown" (Munsell : 10 YR 5/6-5/8) and "dark reddish brown" (Munsell : 5 YR 3/3) soil types show little differences. An average of 24 samples, taken from both soil types at a depth varying between 0 to $75 \mathrm{~cm}$, reveal a Truog value of about 450 p.p.m. $\mathrm{P}_{2} \mathrm{O}_{5}$ and a total phosphate content of $14,7 \% \quad \mathrm{P}_{2} \mathrm{O}_{5}$.

The $\mathrm{pH}$ of these soils lies between 5,5 and 6,5. More or less similar soils were found by Hekstra (1961) during his reconnaissance survey west of Siabes in the Siabes-Wardo area. The soils in this part of the island Biak are in general less reddish; they have higher calcium and potassium contents, a higher $\mathrm{pH}$ and a lower total phosphate content of about $6,5 \% \mathrm{P}_{2} \mathrm{O}_{5}$ as an average.

It is conceivable that the present soils will harden and alter in the course of geological eras and that they may further gain in phosphate content by loosing more of their sesquioxides. Thus, in some distant geological future, the final product may eventually be comparable with phosphorites of the present, such as "Tennesse brown phosphate" or "Florida soft phosphate", which materials are considered to be a product of residual weathering and solution of phosphate containing limestone.

\subsection{Industrial and commercial use}

The phosphatic soils from Ajamaroe do not present an attractive basic material for the manufacture of concentrated phosphatic fertilizers or free phosphoric acid. Phosphatic materials used in the phosphate industry for these purposes normally contain from 30 to $40 \% \quad \mathrm{P}_{2} \mathrm{O}_{5}$. Although there is no doubt that soils with phosphate contents up to $30 \% \mathrm{P}_{2} \mathrm{O}_{5}$ are to be found in the Ajamaroe region, it looks as if only an average of $15 \% \mathrm{P}_{2} \mathrm{O}_{5}$ is to be expected on a larger scale.

A serious obstacle for industrial use is also presented by the high aluminium and iron content of the Ajamaroe soils. In our standard sample B. 6252 these elements amount to $25,1 \% \mathrm{Al}_{2} \mathrm{O}_{3}$ and $15,8 \% \mathrm{Fe}_{2} \mathrm{O}_{3}$. In most phosphatic materials, used in the world phosphate industries, the combined percentages of these sesquioxides seldom amounts to more than $5 \%$. It is obvious that the industrial use of these phosphatic clays presents a purely technological and economic problem, which may be solved later when this undeveloped country will have entered a new era of industrial development.

However, phosphatic soils with a phosphate content of around $15 \%$ could be used commercially without much processing as a slow acting, low-grade phosphatic fertilizer. This would require not more preparatory manipulations than the drying and 
pulverizing of the lumps of phosphatic clay. Such a product may be compared with a material like the "Florida waste pond phosphate" which has a somewhat higher phosphate content of 18 to $27 \% \quad \mathrm{P}_{2} \mathrm{O}_{5}$.

\subsection{Agricultural use}

The value of the phosphatic Ajamaroe soil B. 6252 was tested in our greenhouse. In an observational pot test, a very phosphate deficient soil from Mindiptanah (southern New Guinea) was used and planted with corn as an indicator crop, in order to test the effect of increasing dosages of Ajamaroe phosphatic soil (B. 6252) as compared with certain standard dosages of pure monocalciumphosphate. The soil used, was a very acid, leached, quartzitic silty clay, with a $\mathrm{pH}$ of 4,5 and a Truog value of nil. All pots were limed with $1 \mathrm{~g} \mathrm{CaCO}_{3}$ per $500 \mathrm{~g}$ soil, in order to make the soil suitable for the growth of corn. In order to compensate the general poorness of this soil, all pots received a basic dressing of $100 \mathrm{mg}\left(\mathrm{NH}_{4}\right)_{2} \mathrm{SO}_{4}, 125 \mathrm{mg} \mathrm{K} 2 \mathrm{SO}_{4}$, $500 \mathrm{mg} \mathrm{MgSO}_{4}$ and $5 \mathrm{~g}$ gypsum. The eight phosphate treatments are shown in TABLE 9. The pots were planted with pre-germinated hybrid corn. Strong phosphate deficiency, as shown by a purpling of the lower leaves, developed in the plants of treatments nr. 0 and 1 ; the deficiency showed mildly in treatment $\mathrm{nr}, 2$ and faintly in treatment nr. 3 (see FIG. 5). The plants were reaped after 4 weeks of growth. The fresh weights of 2 plants per pot are presented in triple in TABLE 9 . The average yield figures suggest that the growth in treatment $\mathrm{nr}$. 4 is more or less comparable with growth in treatment $\mathrm{nr}$. 5. Consequently, 9,3 $\mathrm{g} \mathrm{P}_{2} \mathrm{O}_{5}$ contained in $50 \mathrm{~g}$ of Ajamaroe soil $\left(18,6 \% \mathrm{P}_{2} \mathrm{O}_{5}\right)$ exert the same actual effect as $150 \mathrm{mg}$ available $\mathrm{P}_{2} \mathrm{O}_{5}$ supplied as monocalciumphosphate.

When judged on its actual effectiveness during a short period of quick plant growth, it can be said that $100 \mathrm{~g}$ of Ajamaroe soil with $18,6 \% \mathrm{P}_{2} \mathrm{O}_{5}$ is comparable with $1,6 \mathrm{~g}$ of Superphosphate containing $18,6 \%$ water soluble $\mathrm{P}_{2} \mathrm{O}_{5}$.

However, the residual effect of the first material is much greater than that of the equivalent superphosphate dosage. Therefore, it seems that Ajamaroe phosphatic coil could be used advantageously as a starter fertilizer for a tree-crop like rubber, which is grown on the poor, acid, phosphate-fixing soils in the south of West New Guinea. A quantity of about $10 \mathrm{~kg}$, mixed with the soil in the planthole, will give rubber seedlings a good start and sufficient phosphate supply to carry on during the first years of vegetative growth.

TABLE 9. Results of a pot test showing response of maize to phosphate applications

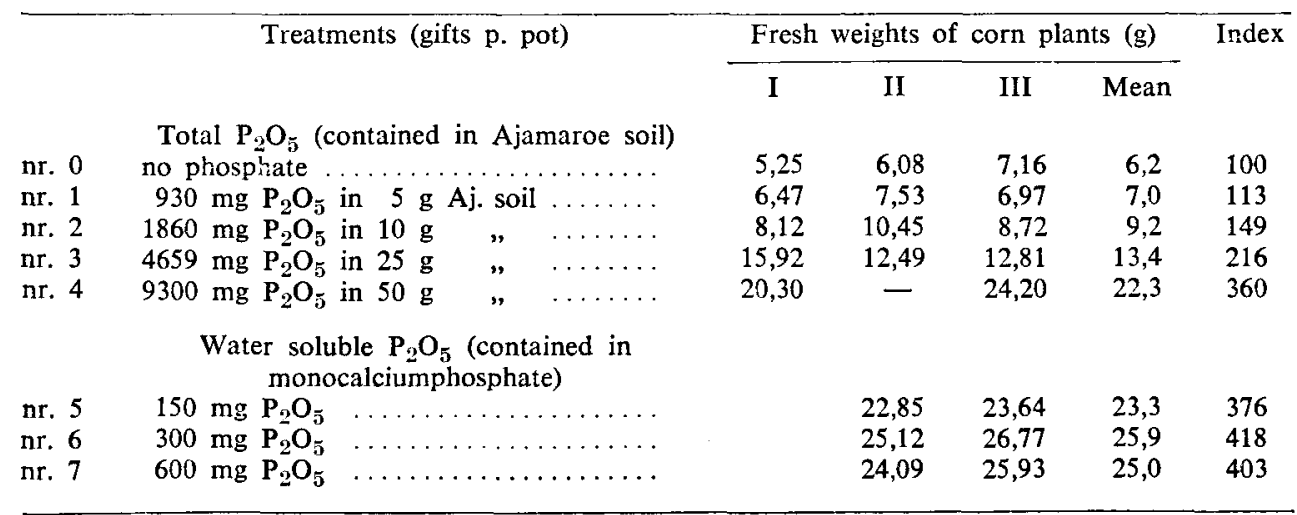




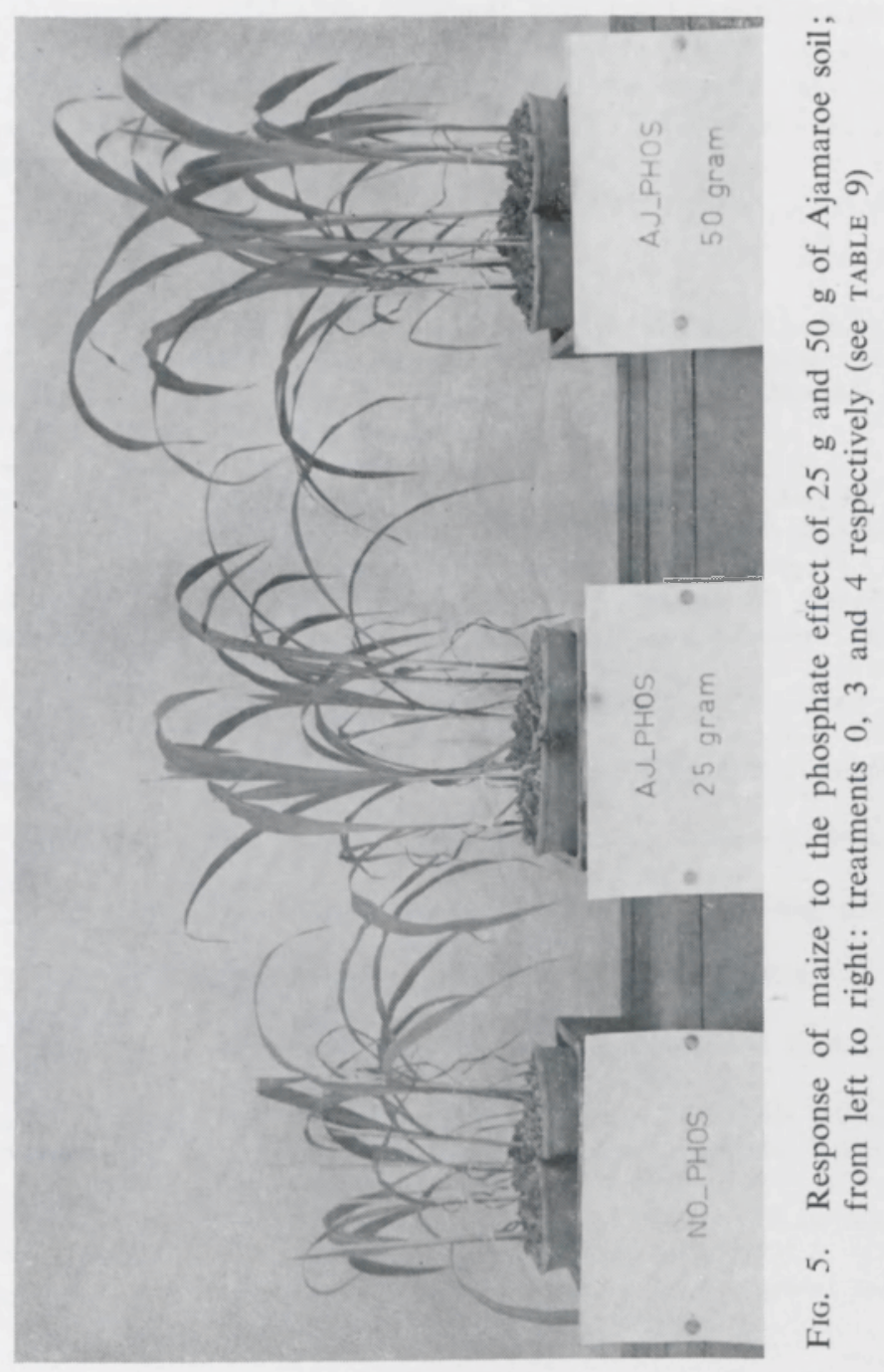




\section{Post Scriptum}

After having submitted this paper for publication, the author received confirmation from Dr. FIELDES (Soil Bureau of the New Zealand Department of Scientific and Industrial Research, Wellington) that standard soil sample B. 6252 contained indeed high contents of Crandallite. His conclusion was based on the presence of a strong endothermic peak near $500^{\circ} \mathrm{C}$ and a strong exothermic peak near $800^{\circ} \mathrm{C}$ of the DTA-pattern; the presence of the two strongest lines for Crandallite, near 2,94 and $2,16 \AA$, in the X-ray pattern supported the DTA-evidence. The X-ray pattern showed fairly diffuse lines, indicating that the Crandallite crystalls were very small.

The author wants to express his indebtness to Dr. M. Fieldes for his most helpful and kind cooperation.

Hollandia, 28th August 1962

Collings, G. H.

Fieldes, M., G. BEALING, 1961

G. G. Claridge,

N. WELIS and

N. H. TAYLOR

Fosberg, F. R.

Hekstra, G.

MoHr, E. C. J., and

F. A. VAN BAREN

NORRISH, K.

Pannekoek, A. J.

RANKAMA, K., and

Th. G. Sahama

Razoux Schultz, F. H. N. 195

REYNDERS, J. J., and F. H. 1958

N. Razoux Schultz

ROGERS, A. F., and

P. F. KERR

SCHROO, H., and

W. L. P. J. MouthaAn

Tercinier, G.

Wegen, G. van DeR

\section{REFERENCES}

1949 Commercial fertilizers. The Blakiston Company, Philadelphia. Minerology and radioactivity of Niue Island soils. Paper submitted to 10th Pacific Sci. Congr. Honolulu, 1961. Also: N.Z. J. Sci. Aug. 1960.

1954 Soils of the northern Marshall atolls. Soil Sci. 78, 2.

1961 Bodemkundige verkenning van de strook tussen Siabes en Wardo op Z.W. Biak (non-published report).

1959 Tropical soils; a critical study of soil genesis as related to climate, rock and vegetation. Interscience Publishers, Ltd., London.

1957 Some phosphatic minerals of soils. Proc. 2nd Austr. Confer. Soil Sci. Vol. I, 2.

1941 Some Karst regions in Indonesia. Ned. Indische Geografische Meded. I.

1949 Geochemistry. The University of Chicago Press.

959 Verslag van een bodemkundige verkenning van een deel van het eiland Biak (non-published report).

Verslag van een bodemkundige verkenning in het Ajamaroe gebied (non-published report).

1933 Thin-section mineralogy. Mc.Graw-Hill Book Comp. Inc.

1960 Voorlopig verslag van een oriënterende potproef met mais, ter beoordeling van Ajamaroe grond als fosfaatmeststof (nonpublished report).

1956 Contribution à l'étude des sols coralliens des atolls. Proc. 6th Intern. Soil Sci. Congr. Paris, 1956.

1960 Rapport fosfaat onderzoek in het gebied ten westen van Ajamaroe (non-published report). 